\title{
PENGARUH WORKING CAPITAL, SALES, OPERATING PROFIT DAN CASH PROFIT TERHADAP DEFAULT SUKUK DI INDONESIA 1 )
}

\author{
Atik Fazalina \\ Mahasiswa Progam Studi S1 Ekonomi Islam Fakultas Ekonomi dan Bisnis Universitas Airlanga \\ Email : atik.fazalina-12@feb.unair.ac.id \\ Raditya Sukmana \\ Departemen Ekonomi Syariah Fakultas Ekonomi dan Bisnis Universitas Airlanga \\ Email : raditya-s@feb.unair.ac.id
}

\begin{abstract}
:
This research aims to determine how four ratios from new altman z-score model affect sukuk default in Indonesia. The case of sukuk default in Indonesia occur by PT Berlian Laju Tanker. These ratios are working capital to total assets, sales to total assets, operating profit to total assets and the cash profit to total assets. Approach used is the logistic regression, as the dependent variable in this research is a dichotomous variable with two categories in the form of default and non-default. The sample used in the period 2007: Q1 to 2015: Q3. The results of this research obtained that the influence of four variables used are the working capital to total assets, sales to total assets, operating profit to total assets and the cash profit to total assets was significant toward sukuk default of Berlian Laju Tanker.
\end{abstract}

Keywords: Default sukuk, Berlian Laju Tanker, New Altman Z-Score Ratio, Logistic regression.

\section{PENDAHULUAN}

\section{Latar Belakang}

Pendanaan menjadi bagian penting dari sebuah perusahaan. terdapat beberapa alternatif untuk mendapatkan sumber pendanaan, salah satunya adalah dengan menerbitan surat utang, baik yang bersifat konvensional maupun syariah atau biasa disebut sukuk. Sukuk atau obligasi syariah kian dilirik oleh banyak perusahaan untuk dijadikan sumber memperoleh pendanaan dari pihak eksternal.

Definisi sukuk diberikan oleh BAPEPAM LK Nomor: KEP-130/BL/2006 tentang penerbitan efek syari'ah, yang dimaksud dengan sukuk adalah efek syari'ah berbentuk sertifikat atau bukti kepemilikan yang bernilai sama dan mewakili bagian penyertaan yang tidak terpisahkan dan tidak terbagi atas kepemilikan asset berwujud tertentu, nilai manfaat dan jasa atas asset proyek tertentu atau aktifitas investasi tertentu, atau kepemilikan atas asset proyek tertentu atau aktivitas investasi tertentu. Jadi sukuk bukan merupakan surat utang namun surat bukti kepemilikan atas suatu asset. Sukuk menjadi alternatif sebagai bentuk penghindaran terhadap riba yang terdapat pada obligasi konvensional. hal ini sesuai dengan Q.S Al Baqarah ayat 275.

Sejak pertama kali dikeluarkan tahun 2002, sukuk mengalami perkembangan yang sangat baik. Hingga November 2015 total jumlah emisi sukuk korporasi sebesar 15.983,40 miliar. Sedangkan nilai sukuk outstanding sebesar 8.284 miliar. Berikut adalah tabel yang menunjukkan perkembangan sukuk dari tahun 2002-per November 2015 :

1) Jurnal ini merupakan bagian dari skripsi yang ditulis oleh Atik Fazalina NIM : 041211432021 , yang diuji pada 20 Juni 2016 
Tabel 1.

Total Emisi Sukuk dan Sukuk Outstanding di Indonesia Tahun 2002 - November 2015

\begin{tabular}{|c|c|c|}
\hline Tahun & $\begin{array}{c}\text { Jumlah } \\
\text { Emisi }\end{array}$ & $\begin{array}{c}\text { Total Nilai Emisi } \\
\text { (Milyar) }\end{array}$ \\
\hline 2002 & 1 & 175 \\
\hline 2003 & 6 & 740 \\
\hline 2004 & 13 & 1.424 \\
\hline 2005 & 16 & 2.009 \\
\hline 2006 & 17 & 2.282 \\
\hline 2007 & 21 & 3.174 \\
\hline 2008 & 29 & 5.498 \\
\hline 2009 & 43 & 7.015 \\
\hline 2010 & 47 & 7.815 \\
\hline 2011 & 48 & $7.915,40$ \\
\hline 2012 & 54 & $9.790,40$ \\
\hline 2013 & 64 & $11.994,40$ \\
\hline 2014 & 71 & $12.956,40$ \\
\hline 2015 & 84 & $15.983,40$ \\
\hline (Nov) & & \\
\hline
\end{tabular}

Sumber : Otoritas Jasa Kevangan. Statistik Pasar Modal Syariah (online). www.ojk.go.id. Data diolah 2015

Disamping perkembangan ini juga perlu diperhatikan risiko yang terdapat pada sukuk. Prinsip-prinsip syariah yang melandasi sukuk tidak menjadikan sukuk sebagai instrumen yang bebas risiko. Konsep risiko tetap ada pada setiap aktivitas yang dijalankan manusia, sebagaimana yang tertera pada AlQuran surat Lukman ayat 43. Salah satunya adalah risiko default (gagal bayar). Sejak awal berkembangnya sukuk baik lingkup global maupun dalam negeri, beberapa sukuk pernah mengalami gagal bayar salah satunya adalah sukuk yang dikeluarkan oleh Dubai World di tahun 2009 yaitu nakheel sukuk. Sedangkan di Indonesia, kasus default sukuk pertama kali terjadi pada sukuk Berlian Laju Tanker. Pada akhir bulan Februari 2012 PT Berlian Laju Tanker Tbk menyatakan kondisi gagal bayar untuk beberapa utang yang dimiliki perusahaan termasuk sukuk ijarah Berlian Laju Tanker I tahun 2007 dan sukuk ijarah Berlian Laju Tanker II tahun 2009 seri A dan seri $B$.

Salah satu faktor yang sangat mempengaruhi keadaan gagal bayar adalah dengan melihat kinerja perusahaan. Samsuddin (2011) menyatakan bahwa rasio keuangan perusahaan memliki pengaruh yang signifikan terhadap probabilitas default sukuk. Selain itu Bandyopadhyay (2006) menggunakan rasio keuangan yang dari Altman Z-Score yang telah direvisi yaitu rasio solvabilitas, working capital to total assets, sales to total assets, operating profit to total assets dan the cash profit to total assets untuk menganalisis kasus gagal bayar obligasi. Keadaan gagal bayar ini akan membawa dampak buruk bagi perusahaan dan menimbulkan kerugian pagi para pemegang sukuk.

Berdasarkan latar belakang diatas, maka rumusan masalah dalam penelitian ini adalah sebagai berikut :

1. Apakah rasio Working capital to total asset berpengaruh signifikan terhadap default sukuk Berlian Laju Tanker ?

2. Apakah rasio Sales to total asset berpengaruh signifikan terhadap default sukuk Berlian Laju Tanker?

3. Apakah rasio Operating profit to total asset berpengaruh signifikan terhadap default sukuk Berlian Laju Tanker?

4. Apakah rasio Cash profit to total asset berpengaruh signifikan terhadap default sukuk Berlian Laju Tanker ? 
Adapun tujuan yang ingin dicapai dari penelitian ini adalah :

1. Untuk mengetahui pengaruh rasio Working capital to total asset terhadap default sukuk Berlian Laju Tanker.

2. Untuk mengetahui pengaruh rasio Sales to total asset terhadap default sukuk Berlian Laju Tanker.

3. Untuk mengetahui pengaruh rasio Operating profit to total asset terhadap default sukuk Berlian Laju Tanker.

4. Untuk mengetahui pengaruh rasio Cash profit to total asset terhadap default sukuk Berlian Laju Tanker.

\section{LANDASAN TEORI}

Menurut bahasa, sukuk berasal dari bahasa arab yaitu sakk, jamaknya sukuk atau sakaik yang berarti memukul atau membentur. Pengertian sukuk yang diberikan oleh DSN-MUI dalam fatwa DSN No. 32/DSN-MUI/IX/2002 sebagai berikut:

"Obligasi syariah adalah suatu surat berharga jangka panjang berdasarkan prinsip syariah yang dikeluarkan Emiten kepada pemegang Obligasi Syariah yang mewajibkan Emiten untuk membayar pendapatan kepada pemegang Obligasi Syariah berupa bagi hasil/margin/fee serta membayar kembali dana obligasi pada saat jatuh tempo".

Sedangkan

Sdangkan jenis-jenis sukuk berdasarkan akadnya, adalah sebagai berikut :

1. Sukuk ljarah, yaitu sukuk yang diterbitkan berdasarkan perjanjian atau akad ljarah di mana satu pihak bertindak sendiri atau melalui wakilnya menjual atau menyewakan hak manfaat atas suatu aset kepada pihak lain berdasarkan harga dan periode yang disepakati, tanpa diikuti dengan pemindahan kepemilikan aset itu sendiri.

2. Sukuk Mudharabah, yaitu sukuk yang diterbitkan berdasarkan perjanjian atau akad Mudharabah.

3. Sukuk Musyarakah, yaitu sukuk yang diterbitkan berdasarkan perjanjian atau akad Musyarakah.

4. Sukuk Istisna', yaitu Sukuk yang diterbitkan berdasarkan perjanjian atau akad Istisna' di mana para pihak menyepakati jual-beli dalam rangka pembiayaan suatu proyek/barang.

Setiap instrumen investasi juga memiliki risiko, baik instrument investasi konvensional maupun instrumen investasi berbasis syariah. Risiko tersebut diantaranya adalah :

1. Risiko gagal bayar (default)

2. Risiko pasar

3. Risiko inflasi

4. Risiko likuiditas

5. Risiko nilai tukar mata uang

Dari beberapa risiko tersebut, risiko gagal bayar merupakan salah satu risiko yang dapat dialami oleh setiap instrumen keuangan termasuk sukuk.

Altman dan Hotchkiss (2006:5) menjelaskan bahwa default merupakan keadaan dimana debitor (perusahaan) melakukan pelanggaran atas perjanjian. Sedangkan default sukuk mengacu pada 
pelanggaran kewajiban dalam perjanjian antara penerbit sukuk dengan pihak investor (pemegang sukuk). Pembayaran pokok dan imbalan dari menjadi sebuah kewajiban yang harus dipenuhi pada saat jatuh tempo. Al Quran menjelaskan bahwa setiap perjanjian dalam akad harus segera dipenuhi, hal ini tercermin dalam Al-Quran surat Al-Maidah ayat 1 berikut ini :

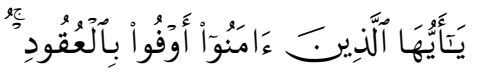

Artinya : Hai orang-orang yang beriman, penuhilah aqad-aqad itu. (Departemen Agama Rl, 2006:141)

Gagal bayar atau default merupakan salah satu keadaan yang berkaitan dengan masalah kevangan perusahaan (financial distress), dimana sebagian besar penyebab utamanya adalah manajemen yang buruk (Altman dan Hotchkiss, 2006:13).

Studi mengenai pertanda masalah keuangan dan kegagalan perusahaan dimulai sejak tahun 1930. Dari beberapa studi yang telah dilakukan menyimpulkan bahwa rasio keuangan berpengaruh signifikan akan terjadinya kegagalan perusahaan (Altman, 1968:589). Salah satu model yang pertama kali hadir adalah model Altman Z-Score yaitu sebagai berikut :

$Z=0,012 X_{1}+0,014 X_{2}+0,033 X_{3}+0,006 X_{4}+$ $0,999 X_{5}$

Dimana :

$\mathrm{Z}=$ Overall Index

$\mathrm{X}_{1}=$ Working capital/Total asset

$\mathrm{X}_{2}=$ Retained earning/Total asset

$\mathrm{X}_{3}=\mathrm{EBT} /$ Total asset
$\mathrm{X}_{4}=$ Market value of equity/Book value of total debt

$\mathrm{X}_{5}=$ Sales $/$ Total assets

Teori Altman Z - Score ini memberikan penjelasan bahwa kegagalan yang terjadi pada sebuah perusahaan disebabkan oleh kinerja keuangan perusahaan yang dinyatakan melalui kelima rasio diatas.

Kemudian Arindam Bandyopadhyay tahun 2006 melakukan perbandingan pada model sebelumnya. Hasilnya menunjukkan bahwa model dari Arindam Bandyopadhyay memiliki tingkat akurasi yang lebih tinggi dan tingkat kesalahan lebih rendah. Model tersebut mengalami perbedaan variabel rasio yang digunakan dengan model Altman Z-Score sebagai berikut :

$Z=-3,337+0,736 X_{1}+6,95 X_{2}+0,864 X_{3}+$ $7,554 \mathrm{X}_{4}+1,544 \mathrm{X}_{4}$

Dimana :

$\mathrm{Z}=$ Overall Index

$X_{1}=$ Working capital/Total asset

$\mathrm{X}_{2}=$ Cash profit/Total asset

$X_{3}=$ Solvency ratio (Total assets/Total liabilities)

$\mathrm{X}_{4}=$ Operating profit/Total assets

$X_{5}=$ Sales/Total assets

\section{Hipotesis dan Model Analisi}

Berdasarkan latar belakang, rumusan masalah dan landasan teori yang telah dipaparkan, maka dalam penelitian ini dapat dirumuskan hipotesis, yaitu :

H1 :Rasio Working capital to total asset berpengaruh signifikan terhadap default sukuk Berlian Laju Tanker 
H2 :Rasio Sales to total asset berpengaruh signifikan terhadap default sukuk Berlian Laju Tanker.

H3 :Rasio Operating profit to total asset berpengaruh signifikan terhadap default sukuk Berlian Laju Tanker.

H4 :Rasio Cash profit to total asset berpengaruh signifikan terhadap default sukuk Berlian Laju Tanker

Sedangkan model analisis yang digunakan dalam penelitian ini adalah :

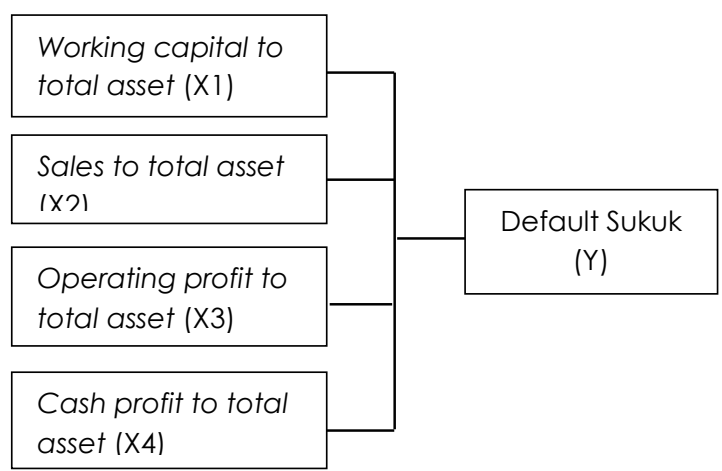

Sumber : Data diolah

Gambar 1. Model Analisis

\section{METODE PENELITIAN}

\section{Pendekatan Penelitian}

Pendekatan yang digunakan dalam penelitian ini adalah pendekatan kuantitatif. Adapun variabel yang digunakan dalam penelitian ini meliputi variabel bebas yang terdiri dari 4 variabel, yaitu rasio Working capital to total asset, rasio Sales to total asset, rasio Operating profit to total asset dan rasio Cash profit to total asset. Sedangkan variabel terikat dalam penelitian ini berjenis binary atau variabel dikotomi berupa default dan non-default. Pemberian kode untuk kedua kategori tersebut adalah kode 0 untuk default dan kode 1 untuk non-default.

\section{Definisi Operasional}

1. Default Sukuk dan Non Default Sukuk Untuk membedakan dua kategori (Default dan Non Default) penulis menggunakan periode dimana sukuk dinyatakan gagal bayar oleh perusahaan sebagai periode cut off. Perusahaan memberikan pengumuman gagal bayar pada tangga 27 Februari 2012 (2012:Q1). Sehingga 2007:Q1 hingga 2011:Q4 dinyatakan dengan kode 1 sebagai non default, sedangkan kuartal 2012:Q1 hingga 2015:Q3 dinyatakan dengan kode 0 sebagai default

2. Rasio Working capital to total asset Working capital merupakan selisih antara aset lancar dengan kewajiban lancar. Rasio working capital terhadap total aktiva yang digunakan adalah perhitungan pada periode 2007:Q1 2015:Q3. Perhitungan rasio Working capital to total asset menggunakan persamaan:

$\mathrm{WC} / \mathrm{TA}=\frac{\text { Aset lancar-kewajlban lancar }}{\text { Total aktiva }}$

3. Rasio Sales to total asset

Rasio ini merupakan perbandingan penjualan perusahaan, dalam hal ini adalah pendapatan dibandingkan dengan total. Rasio Sales to total asset yang digunakan adalah perhitungan pada periode 2007:Q1 - 2015:Q3. Perhitungan rasio Operating profit to total asset menggunakan persamaan : Sales/TA $=\frac{\text { Pendapatan }}{\text { Total aktiva }}$

4. Rasio Operating profit to total asset 
Rasio ini merupakan perbandingan laba operasi dibandingkan dengan total aktiva. Rasio Operating profit to total asset yang adalah perhitungan pada periode 2007:Q1 - 2015:Q3. Perhitungan rasio Operating profit to total asset menggunakan persamaan : OPROF/TA $=\frac{\text { Labs Usghg }}{\text { Total aktiwa }}$

5. Rasio Cash profit to total asset

Cash profit diperoleh dengan menambahkan net profit dengan penyusutan dan amortisasi. Rasio Cash profit to total asset yang digunakan adalah perhitungan pada periode 2007:Q1 - 2015:Q3. Perhitungan rasio Cash profit to total asset menggunakan persamaan :

CASHPROF/TA: $\frac{\text { Net profit+depresiasi +amortisasi }}{\text { Total aktiwa }}$

\section{Teknik Analisis}

Teknik analisis yang digunakan adalah regresi logistik. Regresi logistik digunakan untuk menguji apakah probabilitas terjadinya variabel terikat dapat diprediksi dengan variabel bebasnya (Ghozali dan Ratmono, 2013:336). Persamaan model regresi logistik adalah sebagai berikut :

$\operatorname{Ln}\left(\frac{\mathrm{Pi}}{1-\mathrm{Pi}}\right)=z_{i}=\beta 0+\beta 1 X 1+\beta_{2} X_{2}+\ldots+e$ Keterangan :

$Z_{1} \quad=$ variabel dependen (probabilitas suatu kejadian)

$\beta_{0}=$ konstanta

$\beta_{1}=$ koefisien

$\mathrm{X}_{1}=$ variabel predictor

\section{Uji Multikolinearitas}

Uji multikolinearitas merupakan pengujian yang dilakukan untuk mengetahui ada tidaknya korelasi yang sempurna antara variabel independen dalam model regresi. Menurut Gujarati dan Porter (2011:429), gejala multikolinearitas dapat dideteksi salah satunya dengan cara menghitung koefisien korelasi sederhana antara sesama variabel bebas. Jika koefisien korelasi tersebut melebihi 0,8 (tanpa melihat tanda negatif), maka menunjukkan adanya multikolinearitas dalam regresi.

\section{Nilai Odds Ratio}

Odd ratio merupakan ukuran kecenderungan untuk mengalami kejadian "sukses" antara satu kategori dengan kategori yang lain atau dapat dikatakan sebagai probabilitas kejadian sukses. Bentuk dari odd ratio mempunyai interpretasi untuk $\beta_{1}$ yaitu odd ratio bertambah dengan kelipatan exp $\left(\beta_{1}\right)$ untuk setiap pertambahan satu unit $X_{1}$.

\section{Uji Chi Square Hosmer and Lemeshow's}

Pengujian menggunakan Chi Square Hosmer and Lemeshow's digunakan untuk menentukan kebaikan dan kelayakan model

\section{Cox \& Snell $R$ Square dan Nagelkerke $R$} Square

Cox \& Snell $R$ Square merupakan ukuran yang digunakan untuk menjelaskan kemampuan variabel indepanden dalam menjelaskan variabel depanden. Cox \& Snell $R$ Square didasarkan pada teknik estimasi likelihood dengan nilai maximum kurang dari 1 sehingga sulit untuk diinterpretasikan. Oleh karena itu, digunakan Nagelkerke $R$ Square atau juga disebut dengan Pseudo 
$R$ Square yang merupakan modifikasi dari Cox \& Snell $R^{2}$ untuk memastikan bahwa nilainya bervariasi dari 0-1.

\section{Uji Wald Statistics}

Uji wald digunakan untuk menguji dan membuktikan hipotesis dalam penelitian, apakah masing-masing koefisien regresi logistik signifikan dan apakah terdapat pengaruh variabel bebas terhadap variabel tergantung secara parsial.

\section{HASIL DAN PEMBAHASAN}

Penelitian ini menggunakan analisis regresi logistic dengan jenis data yang dipakai adalah data panel sehingga program yang mendukung untuk melakukan pengolahan regresi logistik data panel adalah STATA 13.0.

\section{Uji Multikolinearitas}

$\begin{array}{rccr}\text { Dalam } & \text { regresi logistik } & \text { tidak } \\ \text { mensyaratkan } & \text { adanya uji } & \text { asumsi }\end{array}$
klasiknnamun pengujian multikolinearitas masih diperlukan untuk melihat korelasi antar variabel bebas (David W. Hosmer, 2011). Hasil uji multikoinieritas sebagai berikut :

Tabel 2.

Hasil Uji Multikolinieritas

\begin{tabular}{|c|c|c|c|c|}
\hline \multirow{2}{*}{\multicolumn{5}{|c|}{$\begin{array}{l}\text { spearman wc_ta sales_ta oprof_ta cashprof_ta } \\
\text { (obs=105) } \\
\qquad \quad \text { wc_ta sales_ta oprof_ta cashpr a }\end{array}$}} \\
\hline & & & & \\
\hline wc_ta & 1.0000 & & & \\
\hline sales_ta & -0.3520 & 1.0000 & & \\
\hline oprof_ta & 0.2400 & 0.0439 & 1.0000 & \\
\hline cashprof_ta & 0.5697 & -0.4357 & -0.0571 & 1.0000 \\
\hline
\end{tabular}

Dari hasil uji multikolinieritas pada tabel tersebut dapat diketahui bahwa nilai korelasi masing-masing variabel tidak ada yang melebihi 0,8 (tanpa melihat tanda negatif) yang artinya menerima $\mathrm{HO}$. Sehingga dapat disimpulkan bahwa tidak ada korelasi sempurna antar variabel independen.

\section{Uji Chi Square Hosmer and Lemeshow's}

Output yang dihasilkan dari uji Chi Square Hosmer and Lemeshow'sadalah seperti pada tabel berikut :

Tabel 3.

Hasil Uji Chi Square Hosmer and Lemeshow's

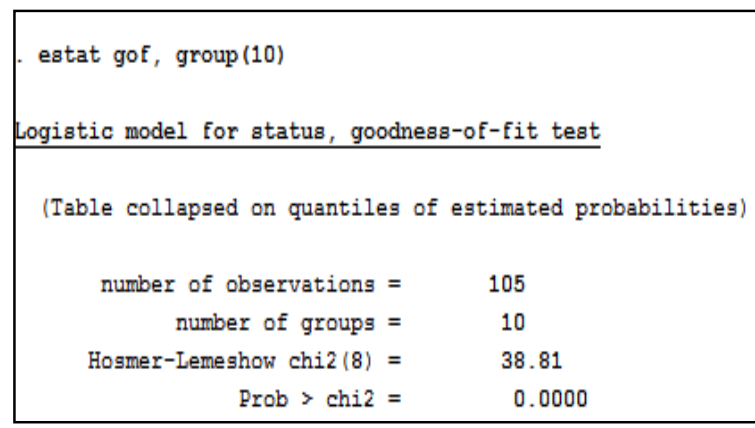

Hasil diatas menunjukkan bahwa nilai prob > chi2 adalah 0,000 dimana nilai ini kurang dari 0,05. Maka HO ditolak dan $\mathrm{HI}$ diterima, yang artinya terdapat perbedaan antara prediksi model dengn hasil observasi sehingga dapat dikatakan model kurang layak. Untuk mengatasi masalah uji chi square hosmer and lemeshow's peneliti menggunakan alternatif penanganan dengan memasukkan variabel interaksi dalam model, yaitu interaksi antara variabel working capital to total asset dengan variabel cashprofit to total asset. Penambahan variabel interaksi ini memiliki pengertian bahwa apakah secara bersama sama variabel working capital to total asset dengan variabel cashprofit to total asset juga memiliki pengaruh 
terhadap default sukuk Berlian Laju Tanker dan dapat memperbaiki kelayakan model. Output yang didapatkan setelah menambahkan variabel interaksi adalah sebagai berikut :

Tabel 4.

Hasil Uji Chi Square Hosmer and Lemeshow's dengan Variabel Interaksi

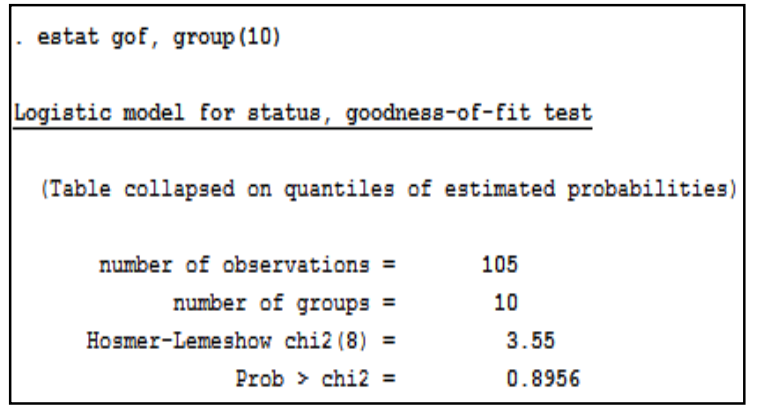

Hasil ini berbeda dengan hasil pada pengujian sebelumnya, dimana nilai prob>chi2 meningkat, yaitu sebesar 0,8218 Sehingga model lolos pada pengujian chi square hosmer and lemeshow's. Dengan adanya variabel interaksi ini, pengujian selanjutnya juga dengan menyertakan variabel interaksi dari working capital to total asset dan cashprofit to total asset.

\section{Uji Hipotesis}

Berikut hasil pengujian hipotesis regresi logistik yang dihasilkan :

Tabel 5.

Hasil Regresi Logistik

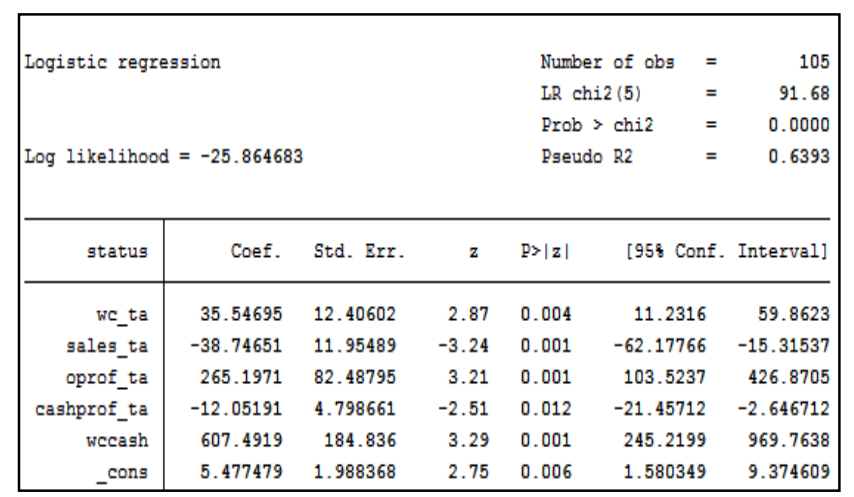

Berdasarkan hasil pengujian hipotesis diatas, maka pengaruh masing-masing variabel independen terhadap dependen sebagai berikut :

1. Variabel WC_TA (Working capital to total asset) memiliki p-value lebih kecil dari a $(0,004<0,05)$. Sehingga disimpulkan bahwa Working capital to total asset berpengaruh secara signifikan terhadap default Sukuk Berlian Laju Tanker.

2. Variabel SALES_TA (Sales to total asset) memiliki $p$-value lebih kecil dari a $(0,001<0,05)$. Sehingga disimpulkan bahwa sales to total asset berpengaruh secara signifikan terhadap default Sukuk Berlian Laju Tanker.

3. variabel OPROF_TA (Operating profit to total asset) memiliki $p$-value lebih kecil dari a $(0,001<0,05)$. Sehingga disimpulkan bahwa Operating profit to total asset berpengaruh secara signifikan terhadap default sukuk Berlian Laju Tanker

4. Variabel CASHPROF_TA /Cash profit to total asset) memiliki p-value lebih kecil dari a $(0,012<0,05)$. Sehingga disimpulkan bahwa Cash profit to total asset berpengaruh secara signifikan terhadap default Sukuk Berlian Laju Tanker.

5. variabel interaksi WCCASH (working capital to total asset dan cashprofit to total asset memiliki $p$-value lebih kecil dari a $(0,001<0,05)$. Sehingga disimpulkan bahwa variabel interaksi WCCASH juga memiliki pengaruh yang 
Fazalina, et al/Jurnal Ekonomi Syariah Teori dan Terapan Vol. 4 No. 3 Maret 2017: 173-186; PENGARUH WORKING CAPITAL, SALES, OPERATING PROFIT DAN CASH PROFIT TERHADAP DEFAULT SUKUK DI INDONESIA

signifikan terhadap default sukuk Berlian Laju Tanker.

Berdasarkan hasil diatas juga didapatkan model regresi logistik sebagai berikut :

$\operatorname{Ln}\left(\frac{p_{i}}{1-q_{i}}\right)=Y=5,477-35,547$ WC_TA + 38,746 SALES $-265,197$ OPROF + 12,052

CASHPROF_TA - 607,492 WCCASH + e

PEMBAHASAN

1. Hubungan rasio working capital to total asset dengan default sukuk.

Berdasarkan output rasio working capital to total asset memiliki pengaruh yang signifikan terhadap default sukuk Berlian Laju Tanker. Arah koefisien positif, artinya bahwa semakin tinggi rasio working capital to total asset kecenderungan perusahaan untuk tidak default (kode 1) juga semakin besar dan kecenderungan perusahaan untuk default (kode 0) akan semakin kecil.

Working capital digunakan untuk dapat mencukupi kebutuhan dana untuk operasional perusahaan termasuk pembayaran utang lancar termasuk adalah pembayaran fee ijarah sukuk. Meskipun sukuk merupakan salah satu utang jangka panjang namun pembayaran fee ijarah dilakukan setiap tiga bulan sekali (triwulan). Dengan working capital yang bagus kewajiban pembaaran sukuk yang termasuk jangka pendek ini dapat dipenuhi dengan baik. Namun working capital Berlian Laju Tanker cenderung rendah. Rasio working capital to total asset Berlian Laju Tanker memiliki pergerakan yang menurun. Salah satu penyebab penurunan rasio ini adalah penurunan laba bersih perusahaan. Berdasarkan laporan tahunan Berlian Laju Tanker, perusahaan mengalami penurunan pendapatan $9,4 \%$ di tahun 2011 dan beban operasional meningkat 22,3\%. Hal ini menyebabkan kerugian operasional sebesar USD 93 juta.

Working capital memiliki peran besar dalam operasional perusahaan dan penyediaan likuiditas perusahaan. Semakin tinggi rasio ini, semakin baik pengaruhnya bagi perusahaan dan kemungkinan gagal bayar lebih kecil. Hal ini sesuai dengan konsep Altman Z - Score yang menyatakan bahwa rasio working capital to total asset merupakan salah satu rasio yang memiliki pengaruh besar terhadap masalah keuangan perusahaan (Altman, 1968).

\section{Hubungan rasio Operating profit to total asset dengan default sukuk}

Berdasarkan output statistik rasio operating profit to total asset memiliki pengaruh yang signifikan terhadap default sukuk Berlian Laju Tanker. Arah koefisien rasio ini memiliki tanda positif, artinya bahwa semakin tinggi rasio operating profit to total asset kecenderungan perusahaan untuk tidak default (kode 1) juga semakin besar dan kecenderungan perusahaan untuk default (kode 0) akan semakin kecil

Operating profit atau laba operasi adalah laba yang didapatkan dari kegiatan usaha pokok perusahaan. Semakin tinggi laba operasi berarti kapasitas perusahaan dalam menghasilkan laba dari aktivitas 
utamanya semakin baik. Laba operasi Berlian Laju Tanker perusahaan mulai mengalami penurunan pada kuartal 4 tahun 2011 hingga sepanjang tahun 2012. Hal ini disebabkan perolehan dari aktivitas operasional perusahaan yang mengalami penurunan dan disebabkan oleh hari menganggur kapal yang lebih tinggi di sepanjang tahun 2011. Operating profit to total asset dari Berlian Laju Tanker mengalami penurunan, hal ini menggambarkan produktivitas perusahaan yang semakin menurun. Dengan adanya penurunan produktivitas perusahaan jumlah kas yang diterima akan mengalami penurunan sehingga menyebabkan perusahaan kesulitan dalam memenuhi kewajiban yang segera harus dibayarkan. Salah satunya adalah pembayaran fee ijarah dari sukuk yang diterbitkan perusahaan.

\section{Hubungan rasio Cashprofit to total asset dengan default sukuk.}

Berdasarkan output statistik yang disebutkan sebelumnya, rasio cash profit to total asset memiliki pengaruh yang signifikan namun arah koefisien rasio ini memiliki tanda negatif, artinya bahwa semakin tinggi rasio cash profit to total asset kecenderungan perusahaan untuk default semakin besar dan kecenderungan perusahaan untuk tidak default semakin kecil. Hasil ini memang terlihat sangat tidak sesuai dengan teori yang ada, namun apabila dilihat lebih rinci pada pergerakan rasio cash profit Berlian Laju Tanker adalah mengalami pergerakan yang cenderung menurun pada tahun 2007 hingga tahun 2012, namun mengalami peningkatan yang sangat signifikan di sepanjang tahun 2013. Hal tersebut dapat dilihat pada gambar dibawah ini :

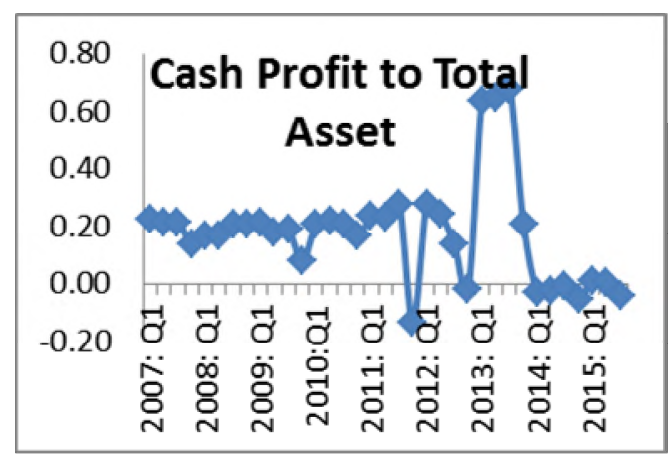

Gambar 2.

Cash Profit to Total Asset Berlian Laju Tanker

Pada tahun 2013 dimana hal ini menimbulkan perolehan kas yang menurun namun meningkat tajam di sepanjang tahun 2013. Kondisi ini disebabkan karena perusahaan melakukan penjualan atas investasi pada Swank Ventures Limited (SVL) dan Nevaeh Limited (NL) berupa saham ekuitas, melakukan penjualan atas 3 kapal yaitu kapal MT Rengganis, MT Ratih dan MT Hyacinth. Selain itu perusahaan juga memperoleh keuntungan restrukturisasi sebesar 317.070 ribu dolar.

Perusahaan memiliki rasio cash profit to total asset yang tinggi, namun hal ini berasal dari penjualan beberapa asset perusahaan bukan berasal dari laba yang diperoleh dari aktivitas operasionalnya. Dengan penjualan asset yang tidak sedikit perusahaan akan kehilangan potensi perolehan laba, sehingga meskipun perusahaan memiliki rasio cash profit to 
Fazalina, et al/Jurnal Ekonomi Syariah Teori dan Terapan Vol. 4 No. 3 Maret 2017: 173-186; PENGARUH WORKING CAPITAL, SALES, OPERATING PROFIT DAN CASH PROFIT TERHADAP DEFAULT SUKUK DI INDONESIA

total asset yang tinggi perusahaan memiliki kemungkinan untuk gagal bayar.

\section{Hubungan rasio Sales to total asset dengan default sukuk}

Berdasarkan output statistik yang disebutkan sebelumnya, rasio salest o total asset memiliki pengaruh yang signifikan terhadap default sukuk Berlian Laju Tanker namun arah koefisien rasio ini memiliki tanda negatif, artinya bahwa semakin tinggi rasio sales to total asset kecenderungan perusahaan untuk default semakin besar dan kecenderungan perusahaan untuk tidak default semakin kecil. Sama halnya dengan hasil dari rasio cash profit to total asset, rasio salest o total asset Berlian Laju Tanker berkebalikan dengan teori yang ada.

Namun yang perlu diperhatikan adalah beban yang ditanggung perusahaan. Meskipun memiliki pendapatan yang cukup baik, biayabiaya yang dianggung perusahaan juga mengalami kenaikan. Beban tersebut diantaranya adalah biaya pelayaran yang meningkat signifikan sebesar $141 \%$ di tahun 2008 seiring dengan penambahan armada perseroan yang diikuti dengan peningkatan biaya sewa dan penyusutan kapal. Di tahun 2010 juga mengalami peningkatan biaya pelayaran sebesar $25,6 \%$ akibat dari kenaikan harga minyak dunia selama tahun 2010. Pertumbuhan pendapatan yang dialami perusahaan belum cukup untuk mengimbangi biaya operasional sehingga terjadi penurunan kinerja perusahaan.
Rasio sales to total asset merupakan salah satu rasio dalam model Altman Z-Score dalam menganalisis masalah keuangan perusahaan dan merupakan rasio kedua yang memiliki pengaruh terbesar pada kepailitan perusahaan (Altman, 1968:596). Rasio ini kembali digunakan oleh Bandyopadhyay (2006) dalam menganalisis gagal bayar obligasi di India dan menunjukkan hasil yang signifkan positif. Namun peningkatan pendapatan tidak selalu menggambarkan perusahaan dalam kondisi baik, juga perlu diperhatikan beban yang harus ditanggung. Hasil dalam penelitian ini sama dengan hasil penelitian Sahida (2014) dalam menganalisis kasus gagal bayar sukuk yang terjadi di Malaysia, dimana rasio sales to total asset berpengaruh signifikan negatif. Kasus gagal bayar sukuk di Malaysia kemungkinan memiliki kesamaan dengan gagal bayar yang terjadi pada Berlian Laju Tanker melihat hasil yang sama.

Sedangkan untuk pengaruh variabel interaksi antara rasio working capital to total asset dan cashprofit to total asset juga memiliki pengaruh signifikan terhadap default sukuk Berlian Laju Tanker. Arah koefisien dari variabel interaksi adalah positif. Hal ini memberikan pengertian bahwa semakin tinggi variabel interaksi antara rasio working capital to total asset dan cashprofit to total asset kecenderungan perusahaan untuk tidak default semakin besar dan 
kecenderungan perusahaan untuk default semakin kecil.

Ketika perusahaan memiliki modal kerja yang tinggi dan memiliki laba bersih yang tinggi pula, dapat dipastikan perusahaan dalam keadaan baik yaitu memiliki likuiditas yang baik dan laba yang tinggi, sehingga perusahaan memiliki kemampuan dalam membayar kewajiban sukuk.

\section{Analisis Hasil Penelitian}

Dari hasil diatas membuktikan bahwa kinerja kevangan memiliki pengaruh besar terhadap kemampuan memenuhi kewajiban, salah satunya adalah pembayaran fee ijarah dan jumlah pokok sukuk yang telah jatuh tempo. Pengaruh ini dinyatakan dengan Pseudo R Square sebesar 63,93\%. Selain itu sebesar $36,07 \%$ penyebabnya dipengaruhi oleh faktor diluar model, seperti nilai tukar, inflasi maupun keadaan ekonomi yang lainnya.

Kinerja kevangan menjadi faktor penting dalam menjelaskan kasus ini. Masalah gagal bayar sukuk pada Berlian Laju Tanker lebih disebabkan oleh kinerja keuangan. Tariq dan Dar (2007) penelitiannya menyimpulkan bahwa default sukuk disebabkan oleh kelayakan kredit dari penerbit sukuk bukan disebabkan oleh struktur yang salah. Ardiansyah (2013) dan Sahida (2014) juga menyampaikan hal yang sama bahwa keadaan default sukuk lebih disebabkan oleh kinerja keuanga penerbit sukuk dan keadaan ekonomi karo dibandingkan dengan disebabkan oleh kesalahan struktur sukuk.

Kasus gagal bayar sukuk dapat menurunkan perspekrif investor pada sukuk, bahwa sukuk yang selama ini dipandang sebagai instrumen keungan islam yang aman ternyata memiliki profil risiko gagal bayar yang tidak kecil.

Dalam kasus gagal baya, investor merupakan pihak yang paling dirugikan. Gagal bayar sukuk ijarah Berlian Laju Tanker, perusahaan tidak dapat memberikan fee ijarah dan pokok ijarah yang seharusnya diterima investor atau pemegang sukuk sehingga menyebabkan kerugian bagi investor. Hal ini tidak sesuai dengan aturan islam yang mengajarkan untuk memenuhi setiap perjanjian yang telah disepakati bersama, dalam Al qur'an surat Al Maidah ayat 1 dijelaskan sebagai berikut :

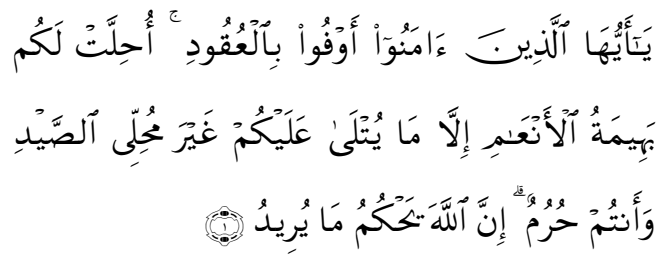

Artinya : Hai orang-orang yang beriman, penuhilah aqad-aqad itu. Dihalalkan bagimu binatang ternak, kecuali yang akan dibacakan kepadamu. (yang demikian itu) dengan tidak menghalalkan berburu ketika kamu sedang mengerjakan haji. Sesungguhnya Allah menetapkan hukum-hukum menurut yang dikehendaki-Nya. (Departemen Agama RI.2006:141)

Perjanjian antara penerbit sukuk dan penerima sukuk yang telah terjadi harus dapat dilaksanakan oleh setiap pihak yang terlibat didalamnya. Hal yang 
sama juga disampaikan dalam surat Al Isra' ayat 34 :

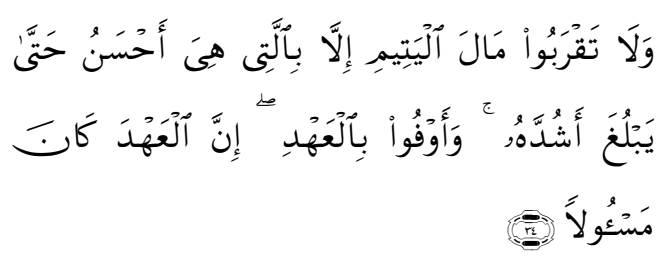

Artinya : Dan janganlah kamu mendekati harta anak yatim, kecuali dengan cara yang lebih baik (bermanfaat) sampai ia dewasa dan penuhilah janji; Sesungguhnya janji itu pasti diminta pertanggungan jawabnya. (Departemen Agama Rl, 2006:389)

Ayat ini menjelaskan lebih lanjut mengenai sebuah perjanjian, yaitu bahwa setiap perjanjian yang dibuat akan diminta pertanggung jawabannya. Pertanggung jawaban ini berlaku di dunia dan diakhirat. Di duni pihak yang melanggar perjanjian dalam hal ini perusahaan Berlian Laju Tanker mendapatkan gugatan dari pemegang sukuk. Selain pertanggung jawaban yang akan diminta, pihak yang tidak memenuhi kewajibannya juga akan mempertanggungjawabkannya di akhirat kelak dihadapan Allah SWT seperti yang tertera dalam Al Qur'an surat Al Isra' ayat 34 diatas.

\section{SIMPULAN}

Berdasarkan hasil analisis dan uji hipotesis dalam penelitian ini, kesimpulan yang dapat diambil adalah sebagai berikut :

1. Rasio working capital to total asset berpengaruh signifikan terhadap default sukuk Berlian Laju Tanker. Hal ini dikarenakan rasio working capital to total asset merupakan salah satu rasio likuiditas yang digunakan untuk melihat kemampuan perusahaan dalam menyediakan kas.

2. Rasio sales to total asset berpengaruh signifikan terhadap default sukuk Berlian Laju Tanker. Namun arah koefisien menunjukkan arah negatif. Dalam kasus gagal bayar sukuk Berlian Laju Tanker, perusahaan memiliki pendapatan yang baik, namun beban yang harus ditanggung juga besar. Sehingga pendapatan yang diperoleh tidak mampu mengimbangi beban yang ada. Sehingga meskipun rasio sales to total asset tinggi perusahaan memiliki kemungkinan untuk gagal bayar.

3. Rasio operating profit to total asset berpengaruh signifikan terhadap default sukuk Berlian Laju Tanker. Hal ini disebabkan karena rasio operating profit to total asset merupakan gambaran dari produktivitas perusahaan.

4. Rasio cash profit to total asset berpengaruh signifikan terhadap default sukuk Berlian Laju Tanker. Namun arah koefisien adalah negatif. Dalam kasus gagal bayar sukuk Berlian Laju Tanker, perusahaan memiliki rasio cash profit to total asset yang tinggi, namun hal ini berasal dari penjualan beberapa asset (kapal tanker) perusahaan bukan berasal dari laba yang diperoleh dari aktivitas operasionalnya. Dengan penjualan asset perusahaan akan kehilangan potensi perolehan laba, sehingga meskipun perusahaan memiliki rasio 
cash profit to total asset yang tinggi perusahaan memiliki kemungkinan gagal bayar.

\section{DAFTAR PUSTAKA}

Altman, Edward I. 1968. Financial Ratio, Discriminant Analysis and The Prediction of Corporate Bankrupty. The Journal of Finance Volume XXIII No 4.

---------dan Edith Hotchkiss. 2006. Corporate Financial Distress and Bankrupty (Third Edition).USA : John Wiley \& Sons Inc

Ardiansyah, Misnen, et al. 2013. Predicting Sukuk Default Probability and Its Relationship with Systematic and Unsystematic Risk : Case Study of sukuk in Indonesia. International ournal of Research in Commerce, Economics and Managemen. Volume no 3 (2013, Issue No 01 January ISSN 2231-4245. (Online). http://ijrcm.org.in/. Diakses pada 15 Oktober 2015.

Badan Pengawas Pasar Modal dan Lembaga Keuangan. 2006. Peraturan Nomor: KEP-130/BL/2006. (Online). www.bapepam.go.id, diakses pada 31 Oktober 2014.

Bandyopadhyay, Arindam. 2006. Predicting probability of default of Indian corporate bonds: logistic and Zscore model approaches. The Journal of Risk Finance Vol. 7 No.3 2006 pp 255272. (Online). www.emeraldinsight.com/15265943.htm. Diakses pada 15 Oktober 2015.

Brigham, Eugene F. dan Joel F. Houston. 2011. Dasar-dasar Manajemen Keuangan, Edisi 11, Penerjemah Ali Akbar Yulianto. Jakarta : Salemba Empat.

Departemen Agama RI. 2006. Mushaf AlQuran dan Terjemahan Revisi Tahun 2006. Jakarta: DEPAG RI

Dewan Syariah Nasional. 2002. Fatwa No. 32/DSN-MUI/IX/2002.

(Online). www.ojk.go.id, diakses pada 31 Oktober 2014.

Dewan Syariah Nasional. 2003. Fatwa No. 40/DSN-MUI/X/2003. www.ojk.go.id, diakses pada 31 Oktober 2014.
Dewan Syariah Nasional. 2004. Fatwa No. $41 / D S N-M U I / I I I / 2004 . \quad$ (Online). www.ojk.go.id, diakses pada 31 Oktober 2014

Ghozali, Imam. 2011. Aplikasi Analisis Multivariate Dengan Program IBM SPSS 19 (edisi kelima). Semarang : Universitas Diponegoro.

----- dan Dwi Ratmono. 2013. Analisis Multivariat dan Ekonometrika. Semarang : Badan Penerbit Universitas Diponegoro

Gujarati, Damodar N dan Dawn C. Porter.2011.Dasar-dasar Ekonometrika. Jakarta : Salemba Empat.

Hosmer, W. David dkk. 2011. Applied Logistic Regression. USA : John Wiley \& Sons Inc.

Merwin, 1942. Financing Small Corporations New York: Bureau of Economic Research.

Otoritas Jasa Keuangan. Statistik Pasar Modal Syariah (online). www.ojk.go.id, diakses pada 31 Oktober 2014.

Sahida, et al. 2014. Predicting Probability of Defaults: The Case of Malaysian Sukuk Market. PROSIDING Persidangan Kebangsaan Ekonomi Malaysia ke-9 (2014) 357 - 365 ISSN: 2231-962X.

Samsuddin, Shamshimah, et al. 2011. Measuring the Default Risk of Sukuk Holders for Shariah Compliance Companies in Malaysia: Using Merton.'s Model with Maximum Likelihood Estimator. IEEE Symposium on Business, Engineering and Industrial Applications (ISBEIA), Langkawi, Malaysia.

Tandelilin, Eduadus. 2010. Portofolio dan Investasi Teori dan Aplikasi. Yogyakarta : Kanisius.

Tariq, A.A. \& H. Dar. 2007. Risks of Sukuk structures: Implications for resource mobilization. Thunderbird International Business Review 49:2. pp. 203-223. Wiley Periodicals, Inc

Wahid, Nazaruddin Abdul. 2010. Sukuk: Memahami \& Membedah Obligasi pada Perbankan Syariah. Yogyakarta: AR-RUZZ MEDIA. 